\title{
Use and distribution of organochlorine pesticides. The future in Africa*
}

\author{
Shem O. Wandiga \\ Kenya National Academy of Sciences, P.O. Box 39450, Nairobi, Kenya
}

\begin{abstract}
Pesticides have been used in the continent for about eight decades. Major use has been in agriculture, livestock development, and disease vectors control. Recent international conventions have been made with little scientific data and information on the tropical situation. Rapid development of resistance to pesticides demands better scientific understanding of pest management. Tropical research data on organochlorine pesticides show rapid degradation pattern, low residue levels, and widespread distribution. Given the above, there is a need to factor into consideration tropical climatological calamities in any future pesticide policy. Continued use of pesticides is anticipated in the tropics.
\end{abstract}

\section{INTRODUCTION}

The exact date of the introduction of synthetic pesticides into Africa is not known with exactitude. They were brought into the continent by colonial powers at around the turn of the first or second decade of the last century. From historical records, the earliest British government legislation, the Public Health Act, to protect human beings and regulate the use of pesticides by farmers in Kenya was enacted in 1921. Therefore, the toxic effects of pesticides were observed very early, soon after their application in the environment. It must be concluded that the early observed adverse effects of pesticides on humans necessitated the regulation of their use and handling. A succession of legislations was passed by the British government and transferred to the colonies as shown by Table 1. The Kenyan dates may not coincide with the dates in other British colonies in Africa, but it may be assumed that pesticides were introduced at around the same time. Assuming that other colonial governments followed the same pattern of pesticide regulation as the British, then it may be concluded that synthetic pesticides have been used in the continent for about 80 years. Three major areas of pesticide use in Africa have been and still remain agriculture, livestock development, and human health.

The large-scale manufacture and distribution of organochlorine pesticides did not take place until after the accidental discovery of p,p'-(dichlorodiphenyl)-1,1,1-trichloroethane (DDT) as an insecticide by Muller in 1946 [1]. Although DDT was first synthesized by Zeidler in 1874 [2], its global use as a pesticide would not have been possible without Muller's observation. In Kenya, lindane was the first organochlorine pesticide introduced in 1949 for the control of ticks. This was followed by the import of toxaphene in 1950, DDT in 1956, and dieldrin in 1961 [3]. It should be recalled that these chemicals were imported for the sole use of white farmers on livestock. The natives came into contact with them only as farm laborers. The spraying of cattle to kill ticks was the major concern and not the protection of the farm laborers.

These organochlorine pesticides would still be in use if it were not for the rapid evolution of ticks to develop resistance to them. Farmers changed to other pesticides, such as dinitrocresol (DNC), and organophosphorous compounds dioxathion, coumophos, and schradon [4] as soon as tick resistance to

*Lecture presented at the $8^{\text {th }}$ International Chemistry Conference in Africa ( $8^{\text {th }}$ ICCA), 30 July-4 August 2001, Dakar, Sénégal. Other presentations are published in this issue, pp. 1147-1223. 
Table 1 Legislation relating to pesticides in Kenya.

\begin{tabular}{|c|c|c|}
\hline Year & Act & Purpose \\
\hline 1921 & Public Health Act & Control the general use and handling of pesticides \\
\hline 1937 & Cattle Cleansing Act & Prescriptions for tick control \\
\hline 1937 & Plant Protection Act & Regulate plant protection practice. \\
\hline 1951 & Water Act, Cap 389 & Regulate water use and controls water additives. \\
\hline 1952 & United Kingdom Act & $\begin{array}{l}\text { Protection of employees against risks of poisoning by } \\
\text { substances used in agriculture }\end{array}$ \\
\hline 1954 & Poisonous Substances Ordinances & $\begin{array}{l}\text { Protection of employees against risks of poisoning by } \\
\text { substances used in agriculture }\end{array}$ \\
\hline 1955 & Agriculture Act & Control pesticide use, distribution, and control \\
\hline 1957 & Pharmacy and Poisons Act, UK & $\begin{array}{l}\text { Control of the profession of pharmacy and the trade in } \\
\text { drugs and poisons }\end{array}$ \\
\hline 1963 & Use of Poisonous Substances Act & $\begin{array}{l}\text { Protect persons from the risk of poisoning by certain } \\
\text { substances }\end{array}$ \\
\hline 1965 & $\begin{array}{l}\text { Food, Drug and Chemical Substance } \\
\text { Act }\end{array}$ & $\begin{array}{l}\text { Prevention of adulteration of food, drugs, and chemical } \\
\text { substances }\end{array}$ \\
\hline 1972 & Factories Act & $\begin{array}{l}\text { Regulate factory working conditions with an aim at } \\
\text { maximizing health protection of workers }\end{array}$ \\
\hline 1972 & $\begin{array}{l}\text { Fertilizers and Animals Foodstuffs } \\
\text { Act, Cap } 345\end{array}$ & Control fertilizers use and animal foodstuff contamination \\
\hline 1983 & Pest Control Products Act & $\begin{array}{l}\text { Regulation of importation, exportation, manufacture, and } \\
\text { distribution of products used for pest control }\end{array}$ \\
\hline 1999 & $\begin{array}{l}\text { Environmental Management and } \\
\text { Coordination Act }\end{array}$ & $\begin{array}{l}\text { Manage and coordinate all statutes dealing with } \\
\text { environment }\end{array}$ \\
\hline
\end{tabular}

organochlorines was observed. Thereafter, importation of organophosphorus pesticides ensued. Development of pest resistance to specific pesticides has necessitated frequent change and introduction of new types such as carbofurans, carbamates, or a new generation of organophosphorus pesticides, chlorfenviphos.

East Africa has had high incidence of tick loads (population) and frequent episodes of East Coast fever or theileriasis [an acute cattle disease transmitted by brown ear ticks Rhipicephalus appendiculatus and caused by Theileria parva (Theiler, 1904)] and anaplasmosis (a peracute to chronic infectious disease of ruminants frequently caused by blood-feeding insects such as ticks). Other tick-borne diseases are cowdriosis and babesiosis. A mortal and similarly related form, corridor disease [T. Parva (Tawrencei)] infection is a buffalo-derived parasite spread by the same tick. The control of these diseases today has relied mainly on acaricides such as chlorfenvinphos [5].

Other pandemic diseases in Africa include malaria, spread by anopheles mosquitoes, river blindness, filariasis (caused by sand flies), and yellow fever, (spread by mosquitoes). These and other vector-borne disease have seen recent increases in incidence and frequency due to global climate change. Malaria alone kills 1 million people per year. The management and control of vectors have relied and still require the use of pesticides, including some of the restricted or banned ones.

Recent international action to protect health and the environment through measures that reduce and/or eliminate emissions and discharges of persistent pollutants (UNEP Governing Council Decision 20/24) have focused attention on the policy-making process. Generally, it is accepted that policy evolution should be based on informed scientific information and technical knowledge. In addition, a policy should enhance a society's social, cultural, political, and economic cohesion and well-being. Therefore, has the international policy on persistent organic pollutants (POPs) used the local and regional scientific information in arriving at the desirability of a convention? This paper examines the available scientific knowledge on POPs in the tropics to find an answer to the question. 


\section{EXISTING PESTICIDES POLICY}

The 1998 Rotterdam Convention on the Prior Informed Consent Procedure for Certain Hazardous Chemicals and Pesticides in International Trade [6] defines POPS to include the following chemicals: 2,4,5-T, aldrin, captafol, chlorobenzilate, chlordane, chlordimeform, DDT, dieldrin, dinoseb, 1,2-dibromoethane (EDB), fluoroacetamide, $\mathrm{HCH}$, heptachlor, hexachlorobenzene, lindane, mercury compounds, pentachlorophenol and certain formulations of methyl-parathion, methamidophos, monocroptophos, parathion, and phosphamidon. Industrial chemicals include the following: crocidolite, polybrominated biphenyls (PBBs), polychlorinated biphenyls (PCBs), polychlorinated terphenyls (PCTs), and tris (2,3-dibromopropyl) phosphate. The convention, which is an internationally binding instrument, aims to reduce the environmental and health risks posed by the above 22 chemicals and pesticides. A more recent development related to the international action to protect human health and the environment is the convention on 12 POPs reached in Durban last year. The targeted POPs are DDT, aldrin, dieldrin, endrin, chlordane, heptachlor, hexachlorobenzene, mirex, toxaphene, polychlorinated biphenyls, dioxins, and furans. While the ill effects of these chemicals are irrefutable, the majority of data and evidence against them have been gathered in temperate regions. Very few resources have been spent on generating tropical regions research data. The few research data available are often ignored when policy decisions are taken.

Experience with international conventions show that few developing countries naturalize them into their laws. However, many do sign the conventions because it is politically prudent to do so. Some of the reasons for lack of full endorsement are:

- low farmers/users education and, therefore, lack of understanding of the regulation

- $\quad$ high economic cost of recommended alternative pesticides as compared to nonrecommended ones. There is also the hard sale push by traders to sell any pesticides for profit gains.

- $\quad$ injury to humans caused by exposure to some pesticides such as organophosphorus

- $\quad$ outbreak of natural pest calamities such as desert locust, malaria, and yellow fever.

- $\quad$ easy availability - there are tens of thousands of tonnes of expired pesticides in the tropics with no proper disposal protocol. Some of these are available in neighborhood stores.

- $\quad$ improper advice given by friends, extension workers, and other agricultural officials to farmers when there is pest outbreak

\section{PESTICIDES USE AND DISTRIBUTION}

\section{Past and current usage patterns}

The import of pesticides into Kenya between 1986 and 1995 is given in Table 2. Analysis of the import quantities by Foxall [7] in 1983 found that 50\% was fungicides, 20\% insecticides, 20\% herbicides, and $10 \%$ arcaricides, rodenticides, molluscides, and nematicides.

It is assumed that this import combination ratio has remained the same in the quantities presented in the table. The bulk of the imported pesticides were consumed locally, with only $3 \%$ being exported to neighboring countries. The decline in imported gross weight of pesticides showed a decline between 1988 and 1991. The reason for this may have been poor economic position of the farmers that reduced demand coupled with the ban/restriction on the use of organochlorine pesticides. The level of pesticides import has not recovered to the 1986/97 levels due to persistent poor economic situation in the country. Before the ban, as much as 70 tonnes of DDT was used annually for agricultural pest control on maize and cotton. Lindane, aldrin, and deildrin were used for seed dressing. However, DDT was banned in Kenya in 1985, the year of the last import; aldrin and dieldrin were banned in 1992. Despite the official ban of these pesticides, they are still available in the market and in the environment. Organochlorine pesticides still officially in use in Kenya are endosulfan, alpha and gamma-BHC, and alachlor. 
Table 2 Importation of different groups of pesticides into Kenya (1986-1995). Quantity in tonnes.

\begin{tabular}{lccccc}
\hline Year & $\begin{array}{c}\text { Insecticides }+ \\
\text { acaricides }\end{array}$ & Herbicides & Others & Fungicides & Total \\
\hline 1995 & 1413.3 & 870.6 & 2323.0 & 501.9 & 5108.8 \\
1994 & 1049.9 & 747.4 & 1671.8 & 563.3 & 4032.4 \\
1993 & 839 & 882 & 1503 & 309 & 3533 \\
1992 & 1670 & 1122 & 2634 & 1164 & 6590 \\
1991 & 1072 & 844 & 1568 & 570 & 4054 \\
1990 & 1572 & 1134 & 1330 & 857 & 4893 \\
1989 & 1571 & 1148 & 4327 & 665 & 7711 \\
1988 & 1089 & 2108 & 4259 & 801 & 8257 \\
1987 & 1206 & 1311 & 715 & 697 & 10371 \\
1986 & 1076 & 112 & 654 & 808 & 9597 \\
\hline
\end{tabular}

Source: Pest Control Products Board.

Pesticides have been widely used for the control of ticks, mosquitoes, houseflies, post-harvest storage insects, tse-tse flies, and as crop pest control and weed control. Frequent application of pesticides has led to the development of resistance, for instance, in Anopheles gambie Giles, to DDT and fenitrothion. No such resistance was observed for pesticides not used for pest control, such as dieldrin and malathion [8]. The development of resistance to insecticides has been a contributor to the resurgence of malaria in many regions. However, since resistance is only developed when direct exposure to insecticides is applied over a period of time, replacement of a pesticide or stoppage of application stops development of resistance. This has been observed in ticks when resistance to DDT and dieldrin were eliminated by use of organophosphorus compounds dioxathion and coumaphos in combination with $\mathrm{HCH}$, toxaphene, or by use of new pesticides such as carbaryl, quintiofos, chlorfenvinphos, and formamidines.

\section{Pesticides in a tropical environment}

Extensive studies of organochlorine pesticides such as DDT have shown that they persist in the environment for a long time. Edward [9] has summarized the persistence of DDT in temperate soils and water as given in Table 3.

It is the persistence of DDT and its breakdown products that leads to its bioaccumulation and bioconcentration in the food chain. The fact that DDT can be stored in fatty tissues and its release and interaction with critical organs has lead to the depletion of some species. At the time DDT was banned, there were no studies in the tropics that showed that DDT elicited the same effects in tropical species.

Table 3 Pesticides residues in temperate soils and water.

\begin{tabular}{lcc}
\hline Insecticide & Half-life in soil (years) & 95\% disappearance (years) \\
\hline Aldrin & 0.3 & 3.0 \\
Isobenzon & 0.4 & 4.0 \\
Heptachlor & 0.8 & 3.5 \\
Chlordane & 1.0 & 4.0 \\
Lindane & 1.2 & 6.5 \\
Endrin & 2.2 & 7.0 \\
Dieldrin & 2.5 & 8.0 \\
DDT & 2.8 & 10.0 \\
\hline
\end{tabular}


The tropics are characterized by high sunshine radiation throughout the year, a high load of microorganisms, tropical rains, and varied soil types, ecology, and climatological conditions. As a result of these conditions, research has now shown that persistent organochlorine pesticides behave differently in the tropics as opposed to the temperate climates. The research data presented here below are derived mainly from research done in our laboratories and other researchers' work in the tropics.

Table 4 Some of the half-lives of DDT in the tropics.

\begin{tabular}{|c|c|c|c|}
\hline Country soil & Half-life in soil (days) & Country soil & Half-life in soil (days) \\
\hline Kenya & & Philippine soils & \\
\hline Nairobi & & Soil, DDT & 210 \\
\hline (Lalah, et al.) DDT & 64.6 & Soil, DDE & 151 \\
\hline (Lalah, et al.) DDE & 145 & & \\
\hline (Wandiga, Mghenyi) DDT & 98 & Brazilian soils & \\
\hline \multirow[t]{2}{*}{ (Natwalsuma, Wandiga) DDT } & 118 & Soil, DDT & 133 \\
\hline & & Water, DDE & 53 \\
\hline Mombasa & & Wooden surface, DDT & 160 \\
\hline (Wandiga, Mghenyi) DDT & 88 & Hawaii soil, DDT & 171 \\
\hline (Nganga) DDT & 270 & & \\
\hline Tanzania & & Nigerian Soil, DDT & 490 \\
\hline Magugu, DDT & 174 & Lindane & \\
\hline Arusha, DDT & 335 & Indian soil (Delhi) & \\
\hline \multirow[t]{3}{*}{ Arusha, DDE } & 233 & $1^{\text {st }}$ phase & 30 \\
\hline & & $2^{\text {nd }}$ phase & 305 \\
\hline & & Overall & 146.5 \\
\hline \multicolumn{4}{|l|}{ Pakistan } \\
\hline Soil, DDT & 133 & Kenya, (Mombasa soil) & \\
\hline Water, DDT & 53 & $1^{\text {st }}$ phase & 5 \\
\hline Thin clay plates, DDT & 160 & $2^{\text {nd }}$ phase & 6 \\
\hline$\underline{\text { Soil, DDE }}$ & 171 & & \\
\hline India & & Kenya (Nairobi soil) & \\
\hline Soil, DDT & 103 & $1^{\text {st }}$ phase & 4 \\
\hline Soil, DDT & 146.5 & $2^{\text {nd }}$ phase & 48 \\
\hline
\end{tabular}

Source: S. O. Wandiga (1996).

Table 4 presents the half-lives of DDT, DDE, and lindane in a tropical climate [10]. The majority of data give half-life of three to seven months, except for the Arusha and Philippines soils. Arusha is at the foot of Mount Kilimanjaro and is relatively cold. The shorter half-life of these compounds has been attributed to differences in ecological, climatological, and microorganism populations in tropical vs. temperate zones.

Differences in species occupying different climatological zones have been exhibited by their responses and sensitivity to exposure of different pesticides. Table 5 gives the $\mathrm{LD}_{50}$ for various fresh lake and ocean fish species. The marked difference in $\mathrm{LD}_{50}$ of white shrimp (Panaeous Seliferus) and Gobious nebulosis fish highlights the species differences.

Tables $6(\mathrm{a}-\mathrm{d})$ and 7 present a summary of the data reported [10] by several authors on the residue levels in tropical soils, birds, fish, and water. It was concluded that bioaccumulation does occur at very low levels compared to that in temperate species. 
Table 5 Species dose response to DDT.

\begin{tabular}{|c|c|c|c|}
\hline Species & Habit & $\mathrm{LD}_{50}$ & Exposure time (h) (temp. $\left.{ }^{\circ} \mathrm{C}\right)$ \\
\hline Tilapia nilotica & $\begin{array}{l}\text { L. Victoria } \\
\text { (fresh water) }\end{array}$ & $0.014 \mathrm{mg} / \mathrm{kg}$ & $24(22)$ \\
\hline Tilapia zili & $\begin{array}{l}\text { L. Naivasha } \\
\text { (fresh water) }\end{array}$ & $0.010 \mathrm{mg} / \mathrm{kg}^{*}$ & $48(22)$ \\
\hline White shrimp & Indian ocean & $0.011 \mathrm{mg} / \mathrm{kg}$ & $24(18)$ \\
\hline Panaeous seliferus & $\begin{array}{l}\text { Mangrove } \\
\text { Swamp }\end{array}$ & & \\
\hline $\begin{array}{l}\text { Fish } \\
\text { Gobious nebulosis }\end{array}$ & $\begin{array}{l}\text { Indian ocean } \\
\text { (Near-shore waters) }\end{array}$ & $0.116 \mathrm{mg} / \mathrm{kg}$ & $24(24)$ \\
\hline
\end{tabular}

Source: Grace W. Mutaaga and B. T. Yebiyo, M.Sc. thesis, Department of Chemistry, University of Nairobi, 1999.

*The concentration killed $40 \%$ of fish in $48 \mathrm{~h}$.

Table 6a DDT residues in Labeo gregorii tissues.

\begin{tabular}{lccc}
\hline Tissue & $\begin{array}{c}\text { Mean fat content } \\
(\%)\end{array}$ & \multicolumn{2}{c}{ Sum $(\Sigma) \mathrm{DDT}$} \\
\cline { 3 - 4 } & 0.27 & 17.14 & 0.13 \\
\hline Muscle & 8.59 & 10.68 & 0.92 \\
Liver & 1.99 & 19.63 & 0.38 \\
Eggs & & & \multicolumn{2}{c}{$\mathrm{mg} \mathrm{kg}^{-1}$ wet mass } \\
\hline
\end{tabular}

Table $6 \mathbf{b}$ Endosulfan residues in Labeo gregorii tissues.

\begin{tabular}{lccc}
\hline Tissue & Mean fat content & \multicolumn{2}{c}{$(\Sigma)$ Endosulfan } \\
\cline { 3 - 4 } & $(\%)$ & $\mathrm{mg} \mathrm{kg}^{-1}$ fat & $\mathrm{mg} \mathrm{kg}^{-1}$ wet mass \\
\hline Muscle & 0.22 & 1.81 & 0.004 \\
Liver & 8.59 & 0.61 & 0.05 \\
Eggs & 1.99 & 0.68 & 0.01 \\
\hline
\end{tabular}

Table 6c DDT residues in C. gariepinus tissues.

\begin{tabular}{lcc}
\hline Tissue & Mean fat content $(\%)$ & $\Sigma$ DDT $\left(\mathrm{mg} \mathrm{kg}^{-1}\right.$ wet mass) \\
\hline Muscle & 0.48 & 0.19 \\
Liver & 3.50 & 2.47 \\
Eggs & 0.49 & 6.01 \\
\hline
\end{tabular}

Table 6d Endosufan residues in C. gariepinus tissues.

\begin{tabular}{lcc}
\hline Tissue & Mean fat content $(\%)$ & $\Sigma$ Endosulfan $\left(\mathrm{mg} \mathrm{kg}^{-1}\right.$ wet mass $)$ \\
\hline Muscle & 0.32 & 0.09 \\
Liver & 3.05 & 0.01 \\
Eggs & 0.49 & 0.07 \\
\hline
\end{tabular}


Table 7 Reported levels of total $\Sigma$ DDT residues in fish from Kenyan lakes.

\begin{tabular}{|c|c|c|}
\hline Species & $\begin{array}{l}\text { Residues concentration } \\
\quad\left(\mathrm{mg} \mathrm{kg}^{-1} \text { mass }\right)\end{array}$ & Source \\
\hline \multicolumn{3}{|l|}{ Lake Baringo } \\
\hline Tilapia nilotica & 0.009 & Lincer et al. [13] \\
\hline Clarias mossambicus & 0.019 & \\
\hline Burbus gregorii & 0.028 & \\
\hline Labeo cylindricus & 0.400 & \\
\hline \multicolumn{3}{|l|}{ Lake Naivasha } \\
\hline Tilapia spirulus and & 0.001 & Lincer et al. [13] \\
\hline \multicolumn{3}{|l|}{ Tilapia lencosticta } \\
\hline Tilapia salmoids & 0.001 & Lincer et al. [13] \\
\hline \multicolumn{3}{|l|}{ Lake Nakuru } \\
\hline Tilapia grahami & 0.015 & Lincer et al. [13] \\
\hline \multicolumn{3}{|l|}{ Lake Victoria } \\
\hline Lates nilotica & 0.004 & Foxall [7] \\
\hline
\end{tabular}

Source: S. O. Wandiga $(1996,1999)[12,14]$.

\section{DIFFERENT NEEDS, DIFFERENT PRIORITIES}

In the tropics, basic needs for survival prevail in all aspects of life. Due to vagaries of weather, people find that their crop harvest may be totally destroyed by either drought or outbreak of pests. First priority is therefore placed on realizing a good harvest. Conservation of environment is often coincidental. Some tropical diseases like malaria and yellow fever have devastating effects on human health. Lately, due to global warming, malaria has spread from lowland areas to highland areas. Three thousand children die per day in Africa due to malaria or lack of public health facilities for a cure. The rapid evolution of resistant mosquitoes to drugs and pesticides further complicate the policy of banning pesticides.

Poisoning by various chemical substances in 19 Kenya hospitals between 1991 and 1993 have been analyzed [11]. From the analysis it was shown that a far greater number of people (27.2\%) were poisoned by the recommended substitutes for organochlorines, the organophosphates. Some of those poisoned who died committed suicide. However, the majority died from handling of the pesticide by an unsophisticated user. A further analysis of the 1888 poisoned cases showed that children between the ages 0 and $14(40.09 \%)$ were affected more than teenagers (19.07\%) and adults (33.63\%). However, the combined workforce, teenagers plus adults, had the highest deaths (52.7\%). Given the standard of education and level of public sophistication of users in the developed world, it is highly unlikely that the effect of toxic substance in the tropics can be repeated in the West.

The distribution of organochlorine pesticides along the Indian Ocean coast of Kenya is given in Figs. 1-3 [12]. The lowest concentration of pesticides was found in water followed by sediment and fish. The concentration levels found were much lower than levels in many parts of the developed world. The near-shore fish sampled were impacted most by human activities inland. Secondly, it was observed that there was fresh use of aldrin in the environment. There were no observed high levels of DDE and DDD in the samples. The observation of most organochlorine pesticides indicates the ubiquitous nature of the pesticides in the tropics. 


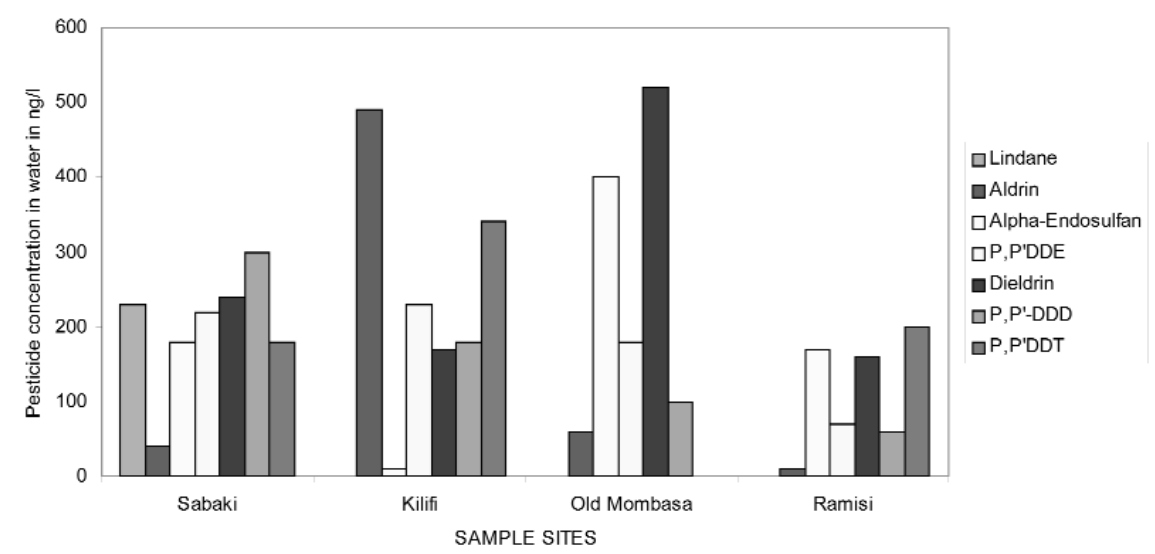

Fig. 1 The observed mean concentration values of pesticides in water from the Kenyan marine environment.

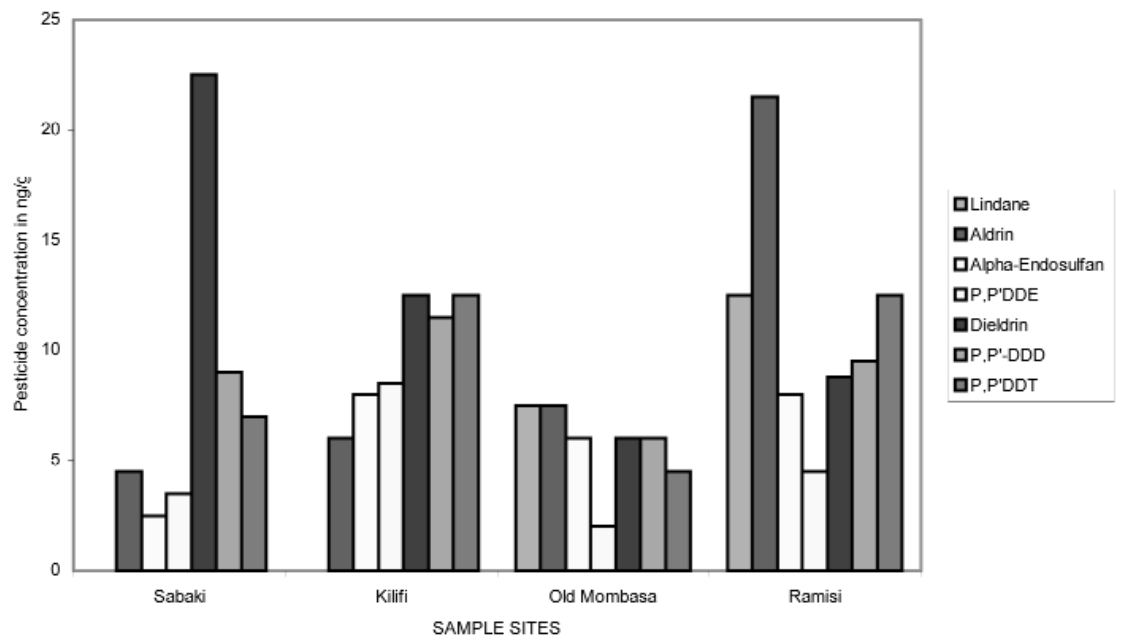

Fig. 2 The observed mean concentration values of pesticides in sediments from the Kenyan marine environment.

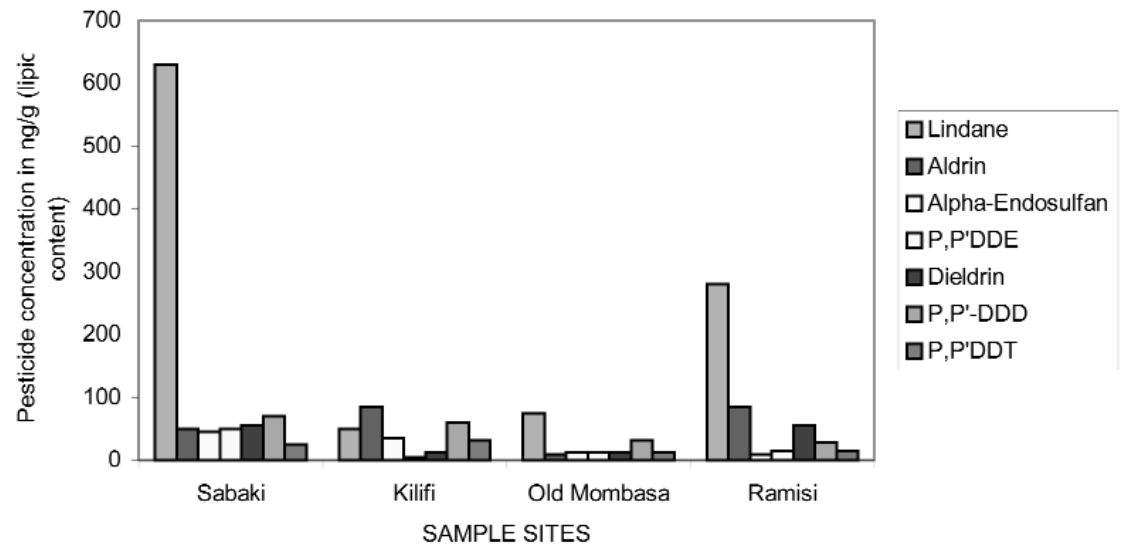

Fig. 3 The observed mean concentration values of pesticides in fish flats of the Kenyan marine environment. 


\section{EXISTING AND FUTURE OPTIONS}

At present, POPs are banned in most countries. Trade in these substances is also restricted. However, some stock of these compounds is still available in the market. Some developing countries allow some use of these compounds for public health purposes, while their use in developed countries for any purpose is banned.

Scientists face the toughest challenge in developing new environmentally friendly pesticides that overcome the rapid development of resistance by insects. Evidence available indicates that humans will never win this battle. Rotation of pesticides used and integrated pest management practices have been recommended as possible solutions to this problem. Policy choice on the pesticide to be used requires data at the local and regional levels, which, in the case of developing countries, are missing.

The level of education in developing countries is low. Proper use of pesticides in these regions will only be met when the standard of education is improved. The challenge for the future is to generate resources for education and research.

Disposal of pesticides requires heavy investment that is beyond the financial resources available to most developing countries. The challenge here is first to develop human capacity in waste management and research in order to install facilities for POP disposal in the south. It is possible that African countries could seek research support that could provide the scientific information needed. Therefore, it may be concluded that present international conventions have been passed without Africa's scientific contribution to the debate. Their full implementation may not be to the benefit of Africans.

\section{REFERENCES}

1. P. Muller. Helv. Chim. Acta 29, 1560-1580 (1946).

2. A. Zeidler. Ber. 7, 1180-1181 (1874).

3. K. W. S. Kaine. Bull. de L' Office, International, Epiz 86, 71-75 (1996).

4. M. I. Keating. Trop. Animal. Heth. Prod. 15, 1-6 (1983).

5. E. N. Kituyi, S. O. Wandiga, I. O. Jumba. Bull. Environ. Contain. Toxicol. 58, 969-975 (1997).

6. The Rotterdam Convention on the Prior Informed Consent Procedure for Certain Hazardous Chemicals and Pesticides in International Trade. Available at Convention Web site: http://irptc.unep.ch/pic/incs/dipcon/convsumm.htm

7. C. D. Foxall. Swara 6, 25 (1983).

8. L. M. A. Okedi. Evaluation of resistance to insectides in the mosquito larvae of Anopheles gambie Giles and its control by two microbial bacteria pathogens. M.Sc. thesis, Department of Zoology, University of Nairobi, Kenya (1988).

9. C. A. Edwards. "Pesticides residues in soil and water". In Environmental Pollution by Pesticides, Plenum Press, London (1973).

10. S. O. Wandiga. "Organochlorine pesticides: Curse or blessing in tropical agriculture?" In Environment and Development, S. O. Wandiga and N. L. Abuodha (Eds.), pp. 62-92, Kenya National Academy of Sciences, Public Lecture Series, KNAS Press, Nairobi, Kenya (1996).

11. C. K. Maitai, I. O. Kibwage, A. N. Quantai, J. N. Ombega, F. N. Ndemo. J. Pharm. Sci. 1(1) 7-10 (1988).

12. S. O. Wandiga, P. O Yugi, M. W. Barasa, I. O. Jumba, J. O. Lalah. Environ. Technol. (2001). In press.

13. J. L. Lincer, D. Zabkind, L. H. Brown, J. Hopcraft. J. Appl. Ecol. 18, 157 (1981).

14. S. O. Wandiga, J. O. Lalah, P. N. Kaigwara. "Pesticides in Kenya". In Distribution, Fate and Effects of Pesticides in Tropical Coastal Zones, F. P. Carvalho, S. Klein, M. D. Taylor (Eds.), IAEA. In press. 